ISSN (Print) : 1412-7601

ISSN (Online) : 2654-8712

Volume 7, No.2 September 2021

EKONOBIS

http://www.ekonobis.unram.ac.id

\title{
Peluang dan Tantangan UMKM NTB Dalam Menghadapi Masyarakat Ekonomi Asean (Mea) 2015
}

\section{Irwan Suriadi.}

Universitas Mataram

\begin{tabular}{l|l}
\hline A R TICLE I N F O & ABSTRACT : The purpose of this study was to measure the extent of readiness of SMEs \\
\hline Keywords: & in the West Nusa Tenggara in capturing opportunities for business development as \\
Opportunities, & well as to see the extent of the challenges to be faced by the SMEs in the NTB in the \\
2015 & face of the ASEAN market with 2015 cases in this research is the lack of readiness of \\
& SMEs in NTB in seeing the opportunities and challenges facing Asean economic \\
& Community (AEC) in 2015. \\
& To overcome this problem researchers conducted a descriptive analysis of the SMEs \\
& which are in NTB to see the extent of the opportunities that can be utilized as well as \\
& the challenges to be faced in the form of threats from fellow competitors in other \\
& ASEAN countries. To analyze the opportunities and challenges that needed secondary \\
& data pertaining to SMEs in West Nusa Tenggara \\
\hline Kata Kunci: & ABSTRAK: Tujuan dari penelitian ini adalah untuk mengukur sejauh mana kesiapan \\
Peluang, Tantangan, & UMKM di Nusa tenggara barat dalam menangkap peluang bagi pengembangan usaha \\
UMKM, MEA 2015 & sekaligus untuk melihat sejauh mana tantangan yang akan dihadapi oleh UMKM di \\
& NTB dalam menghadapi pasar bersama ASEAN 2015. Permasalahan dalam penelitian \\
& ini adalah belum adanya kesiapan dari UMKM di NTB dalam melihat peluang dan \\
& tantangan dalam menghadapi masyarakat ekonomi asean (MEA) 2015. \\
& Untuk mengatasi masalah ini peneliti melakukan analisis deskriptif terhadap UMKM \\
& yang berada di NTB dengan melihat sejauh mana peluang yang dapat dimanfaatkan \\
& serta tantangan yang akan dihadapi berupa ancaman dari pesaing sesame Negara \\
& ASEAN lainnya. Untuk menganalisis peluang dan tantangan tersebut dibutuhkan data \\
& sekunder yang berkaitan dengan UMKM di Nusa Tenggara Barat \\
\hline
\end{tabular}

Corresponding Author:

Alamat : Program Studi Ekonomi Pembangunan, Fakultas Ekonomi dan Bisnis, Universitas Mataram, Jln. Majapahit No. 62 Mataram.

e-mail: 


\section{PENDAHULUAN}

\section{Latar Belakang}

Perkembangan UMKM di nusa tenggara barat menunjukkan perkembangan yang cukup menjanjikan, di mana perkembangan tersebut terlihat dari kucuran kredit perbankan per tanggal 1 januari 2014 sebesar 625.936 Miliar Rupiah, artinya semakin banyak kredit yang disalurkan maka semakin besar juga kontribusi UMKM dalam menyumbang pertumbuhan ekonomi di Nusa Tenggara Barat. UMKM di NTB cukup variatif mulai dari usaha pangan rumahan sampai dengan usaha kerajinan kreatif yang bahkan sudah menembus pasar luar negeri.

Dengan adanya liberalisai perdagangan antar Negara-negara asia tenggara (ASEAN) atau lebih dikenal dengan sebutan MEA yang mulai akan berlaku pada tahun 2015 ini diprediksi akan mempengaruhi kegiatan UMKM di Indonesia pada umumnya dan NTB pada khususnya yang menyebabkan seluruh UMKM di NTB harus mempersiapkan diri dalam menghadapi MEA 2015 ini dengan memperkuat internal UMKM itu sendiri dengan menghasilkan produk yang berkualitas dan berdayasaing yang tinggi serta penerapan manajemen modern yang berbasis UMKM.

Permasalahan yang dihadapi UMKM di Indonesia dan NTB pada umumnya memiliki persamaan diantaranya permasalahan permodalan yang menjadi masalah klasik yang membutuhkan penyelesaian secepatnya oleh pengambil kebijakan (pemerintah) agar dapat bersaing dengan UMKM Negara ASEAN lainnya.
Tabel 1. kendala-kendala utama yang dihadapi oleh UMKM

\begin{tabular}{|l|c|r|}
\hline \multicolumn{1}{|c|}{ Jenis Kendala } & $\begin{array}{c}\text { Banyaknya } \\
\text { Usaha }\end{array}$ & \multicolumn{1}{|c|}{ Persentase } \\
\hline Modal & $\mathbf{( 2 )}$ & $\mathbf{( 3 )}$ \\
\hline Pemasaran & 3.899 .264 & 35,7 \\
\hline Bahan Baku & 3.795 .953 & 34,8 \\
\hline BBM/Energi & 1.173 .911 & 10,8 \\
\hline Transportasi & 344.340 & 4,1 \\
\hline Keterampilan & 133.329 & 2,8 \\
\hline Upah Buruh & 95.128 & 1,2 \\
\hline Lainnya & 1.073 .802 & 0,8 \\
\hline
\end{tabular}

Sumber: Kuncoro (2003)

Dari tabel diatas permasalahan permodalan menjadi kendala utama dalam mengembangkan UMKM termasuk di Nusa Tenggara Barat (NTB), dimana UMKM di NTB tidak akan berkembang jika tidak memiliki permodalan yang kuat dan memadai, meskipun pemerintah sudah mulai mengucurkan bantuan kredit dalam bentuk Kredit Usaha Rakyat (KUR) untuk mengatasi permasalah permodalan UMKM, akan tetapi belum cukup perlu adanya bantuan permodalan langsung dalam bentuk Hibah yang dikelola oleh BUMN atau BUMD didaerah terutama di NTB agar mampu bersaing dengan UMKM Negara ASEAN lainnya.

Permasalahan atau tantangan yang dihadapai oleh UMKM di Indonesia da NTB pada khususnya selain masalah/kendala permodalan yang dihadapi adalah masalah pemasaran, kurangnya keahlian, bahan baku dan sebagainya.

Disamping permasalahan atau kendala yang dihadapi oleh UMKM di NTB, terdapat juga Peluang yang dmiliki oleh UMKM di NTB diantaranya perekonomian NTB sedang tumbuh dan berkembang. 
Selain sebagai tujuan prioritas pembangunan di Indonesia timur, NTB juga dijadikan sebagai program percepatan ekonomi nasional yang disebut dengan MP3El. Pengembangan NTB sebagai prioritas pembangunan nasional dititik beratkan dalam bidang pariwisata karena NTB memiliki potensi pariwisata yang cukup baik terutama wisata alam yang indah. Dengan adanya MP3EI ini diharapkan wisatawan akan banyak berkunjung ke NTB baik dari Negaranegara Eropa, Asia, Amerika maupun dari Negara-negara ASEAN, dimana dengan banyaknya kunjungan wisatawan tersebut diharapkan akan memberikan peluang bagi UMKM di NTB untuk menjual langsung produknya dan sekaligus mempromosikan dan memperkenalkan produk UMKM di NTB kepada para wisatawan.

Dengan adanya pasar bebas antara Negara-negara ASEAN yang memberikan peluang bagi UMKM di NTB untuk berkembang meskipun terdapat tantangan-tantangan yang dihadapi oleh UMKM berupa berbagai permasalahan/kendala yang masih melekat pada UMKM di NTB, maka peneliti mengambil judul penelitian yang berjudul "Peluang Dan Tantangan UMKM NTB Dalam Menghadapi Masyarakat Ekonomi Asean (MEA) 2015"

\section{Tujuan Penelitian}

Tujuan penelitian ini adalah untuk menganalisis peluang dan tantangan yang dihadapai oleh UMKM di NTB dalam menghadapi Masyarakat Ekonomi Asean (MEA) tahun 2015

\section{Manfaat Penelitian}

Sebagai panduan bagi pemerintah dalam menentukan kebijakan dalam mengembangkan dan sekaligus mempersiapkan UMKM di NTB dalam menghadapi masyarakat ekonomi ASEAN (MEA)

Sebagai panduan bagi pemerintah dalam membuat kebijakan dalam membantu mengatasi permasalahan-permasalahan yang di hadapi oleh UMKM di NTB seperti permasalahan permodalan, akses pasar dan sebagainya.

Sebagai acuan bagi UMKM di NTB dalam bersaing dengan UMKM Asia tenggara lainnya.

\section{KAJIAN PUSTAKA}

\section{Usaha Mikro Kecil Menengah (UMKM)} Menurut UU No 9 tahun 1995, Usaha Kecil adalah kegiatan ekonomi rakyat yang memiliki hasil penjualan tahunan maksimal 1 Miliar rupiah dan memiliki Kekayaan bersih 200 juta rupiah (tidak termasuk tanah dan bangunan tempat usaha)

Menurut BPS, Usaha Kecil merupakan usaha yang identik dengan Industri kecil dan rumah tangga dengan pekerja 1-4 orang untuk industri rumah Tangga, industri kecil dg pekerja 5-19 orang dan industri menengah dg Pekerja 20-99 orang

\section{Perdagangan Internasional}

Teori klasik yang berkaitan dengan perdagangan internasional berkaitan dengan teori Absolut advantage (Adam Smith) dan teori comparative advantage (David Ricardo) (Krugman \& Obstfeld,2003)

1. Teori Absolut advantage (Adam Smith) menyatakan bahwa masing-masing 
negara dapat menghasilkan satu jenis barang dg biaya tenaga kerja yg secara absolut lebih rendah dari negara lain. Teori ini mengukur nilai suatu barang dg menggunakan banyaknya tenaga kerja yg dikeluarkan untuk menghasilkan suatu barang, semakin banyak tenaga kerja yg digunakan maka nilai suatu barang akan semakin tinggi, Jadi Keunggulan absolut merupakan kemampuan suatu negara untuk memproduksi suatu barang yang lebih murah dari negara lain, contoh : Arab Saudi memiliki produksi minyak terbesar di dunia, brazil memiliki produksi kopi terbesar didunia. (Nopirin,1999)

2. Teori comparative advantage (David Ricardo) menyebutkan bahwa Nilai suatu barang ditentukan oleh banyaknya tenaga kerja yg digunakan untuk memproduksi barang, makin banyak tenaga kerja yg digunakan untuk memproduksi suatu barang maka akan semakin mahal barang tersebut. Suatu negara akan memproduksi barang dan kemudian mengekspor suatu barang yg memiliki comparative advantage terbesar, Jadi Keunggulan komparatif merupakan kemampuan suatu Negara untuk memproduksi beberapa produk lebih baik dari negara lain. Contoh : Amerika Serikat memiliki keunggulan dalam industry computer (teknologi), Korea selatan memiliki keunggulan dibidang manufactur alat-alat elektronik (Nopirin,1999)

Adapun bentuk-bentuk Perdagangan Internasional diantaranya adalah:

1. Free trade area, dibentuk untuk menghapus bea masuk impor dari negara anggota saja, contoh European FTA, AFTA, AEC dan sebagainya

2. Pasar bersama (common markets), dibentuk untuk pengenaan tarif yg seragam untuk negara lain

3. Customs unions, dibentuk untuk proteksi terhadap produk-produk negara anggota

\section{Masyarakat Ekonomi ASEAN (MEA)}

MEA merupakan liberalisasi perdagangan internasional antara Negara-negara yang tergabung kedalam Negara asia tenggara (ASEAN) yang dapat berpengaruh positif maupun negatif bagi perusahaanperusahan local, terutama Usaha Mikro Kecil Menengah (UMKM).

\section{Pengaruh positif dan negatif MEA terhadap perusahaan lokal}

Terdapat empat cara yang dapat mempengaruhi secara positif dan negatif perusahaan-perusahaan lokal pada saat penerapan MEA (Tambunan, 2012):

1. Peningkatan persaingan di pasar domestic melalui tariff impor yag rendah atau nol dan tidak adanya pembatasan kuota

2. Penurunan biaya produksi, karena tidak adanya tariff impor dan quota maka harga bahan baku input menjadi murah

3. Peningkatan ekspor

4. Pengurangan kesediaan bahan baku atau input di pasar dalam negeri.

\section{Pengembangan UMKM dalam kerangka AEC 2015}

Pengembangan UMKM dalam kerangka AEC 2015 dilaksanakan dalam rangka menuju pertumbuhan ekonomi yang merata, yang pelaksanaannya mengacu 
pada ASEAN Policy Blueprint for SME Development (APBSD) 2004 - 2014, pengembangan UMKM dilaksanakan melalui 5 program yaitu (Direktorat Kredit, BPR dan UMKM; 2009):

1. Program pengembangan kewirausahaan

2. Peningkatan kemampuan pemasaran

3. Akses kepada keuangan

4. Akses kepada teknologi

5. Menciptakan kebijakan yang kondusif. Dari kelima program pengembangan UMKM tersebut akses kepada keuangan merupakan permasalahan yang paling besar karena kekurangan informasi dan kemampuan untuk menjadi bankable. Terdapat 3 kendala/gap antara UMKM dan perbankan (Direktorat Kredit, BPR dan UMKM; 2009)

1. Gap informasi, yaitu gap antara informasi produk bank serta prosedur perbankan dengan yang dimiliki UMKM

2. Gap formalitas, yaitu gap antara formalitas dokumen serta prosedur yang harus dipenuhi UMKM dan yang saat ini dimiliki UMKM

3. Gap skala usaha, yakni jumlah kredit yang diharapkan UMKM dan yang direalisasikanoleh bank.

\section{Kajian Penelitian Terdahulu}

Tambunan (2012) melakukan penelitian yang berjudul "Peluang, Tantangan Dan Ancaman Bagi UMKM Indonesia Dalam Era CAFTA Dan ME-ASEAN 2015" tujuan penelitiannya adalah mengkaji seberapa besar kemungkinan tantangan, peluang dan bahkan ancaman yang dihadapi UMKM Indonesia dalam era pasar bebas. Khususnya akibat penerapan kesepakatan pasar bebas antara ASEAN dengan China (CAFTA) dan pemberlakuan masyarakat ekonomi ASEAN (ME-ASEAN) pada tahun 2015 nanti. Jenis penelitiannya adalah penelitian deskriptif yang didasarkan pada analisis data sekunder khususnya data BPS dan studi literatur kunci mengenai dampak dari liberalisasi perdagangan terhadap UMKM dimana analisa ini cenderung menyimpulkan bahwa secara umum UMKM di Indonesia berpotensi "terkalahkan" di dalam persaingan di pasar tunggal ASEAN.

Hasil penelitiannya menunjukkan bahwa daya saing UMKM Indonesia paling rendah dibandingkan UMKM di sejumlah ekonomi APEC lainnya yang diteliti. Ini menimbulkan keraguan mengenai kemampuan UMKM Indonesia, khususnya UMI yang mendominasi jumlah UMKM di tanah air, untuk mampu bersaing di pasar regional (misalnya ASEAN atau APEC) atau dunia, atau bahkan untuk bisa mempertahankan pangsa pasar domestik dengan semakin dasyatnya barang-barang impor membanjiri pasar dalam negeri.

Tim peneliti dari direktorat kredit, BPR dan UMKM tahun 2009 melakukan penelitian yang berjudul" Kajian Mengenai Standar Minimum Laporan Keuangan dan Business Plan untuk UMKM, Persiapan BI Dalam Menghadapi Masyarakat Ekonomi Asean (MEA) 2015 terkait dengan Tugas BI". Tujuan penelitiannya adalah:

1. Melakukan kajian rumusan standar minimum business plan untuk UMKM yang secara umum diterima oleh perbankan di negara-negara ASEAN, meliputi berbagai aspek yang menjadi concern pihak perbankan.

2. Melakukan identifikasi pentahapan penerapan pedoman penyusunan laporan keuangan sesuai SAK ETAP untuk masing-masing skala usaha. 
3. Menyusun program pelatihan untuk penerapan SAK tersebut untuk masing-masing skala usaha.

Alat analisis yang digunakan adalah Analisis SWOT (Strength, Weakness, Opportunity, Threat) atas seluruh informasi yang diperoleh. Subyek analisis dalam hal ini adalah kelompok UMKM sebagai satu entitas dan dengan tujuan tercapainya penyusunan Laporan Keuangan UMKM berdasarkan SAK ETAP. Data penelitian terdiri dari Jumlah responden adalah 45 UMKM, Daerah penelitian terdiri dari DKI Jakarta dan sekitarnya, Jawa Barat dan Jawa Timur dengan jumlah UMKM yang proporsional untuk setiap daerah penelitian, Kriteria UMKM yang menjadi responden adalah UMKM yang belum pernah berhubungan/mendapatkan kredit dari perbankan

Susilo (2010) meneliti tentang Strategi Meningkatkan Daya Saing UMKM Dalam Menghadapi Implementasi CAFTA Dan MEA. Tujuan penelitiannya adalah memberikan rekomendasi dalam bentuk strategi Meningkatkan Daya Saing UMKM Dalam Menghadapi Implementasi CAFTA Dan MEA. Metode penelitian yang digunakan adalah metode penelitian literature review.

\section{HASIL DAN PEMBAHASAN}

\section{Analisis Peluang UMKM NTB dalam menghadapi MEA}

Dilihat dari faktor eksternal Negara-negara ASEAN, Peluang yang dimiliki oleh pelaku usaha atau UMKM di Nusa Tenggara Barat cukup besar dimana jumlah pasar ASEAN yang cukup besar yang mencapai 500 juta dollar Amerika dengan pertumbuhan kelas
Hasil penelitiannya menyebutkan bahwa Agar UMKM di Indonesia tetap mampu bertahan dan memanfaatkan peluang dari pelaksanaan CAFTA dan MEA, maka usaha kecil harus meningkatkan daya saing bisnis dan daya saing produk mereka, Pengusaha/pemilik usaha kecil harus memiliki kewirausahaan dan inovasi yang menjadi kekuatan pendorong untuk meningkatkan daya saing bisnis mereka. Dengan meningkatkan bisnis dan daya saing maka pada gilirannya akan mendorong terciptanya daya saing produk. Hal-hal lain yang harus menjadi prioritas dari usaha kecil yang dapat meningkatkan kerja sama antara unit-unit usaha kecil atau antara pusat-pusat usaha kecil dan juga meningkatkan jaringan kerjasama dengan stakeholders terutama pemerintah. Peran pemerintah diharapkan sebagai pelengkap untuk mendorong berbagai upaya untuk meningkatkan daya saing UMKM. Dengan usaha yang kondusif iklim yang diciptakan oleh pemerintah itu akan memfasilitasi UMKM untuk meningkatkan daya saing. Pemangku kepentingan lainnya harus meningkatkan kemitraan yang diciptakan oleh UMKM, baik dalam bentuk pendidikan dan pelatihan, promosi, dan sebagainya.

menengah yang semakin meningkat dimana kelas menengah di Negara ASEAN mencapai 24\% pada tahun 2010 dan diperkirakan akan meningkat pada tahun 2030 yang dapat mencapai peningkatan sebesar 65\%. Selain itu juga kebijakan makro ekonomi Negara-negara ASEAN cukup mendukung yang dapat mendukung peningkatan peluang masuknya Foreign Direct Investment dari luar negeri dimana sampai dengan tahun 2010 total Foreign 
Direct Investment dari luar negeri yang masuk ke Negara-negara ASEAN telah mengalami peningkatan yang cukup signifikan mencapai $75 \%$. Selain itu juga tingkat pertumbuhan ekonomi Negaranegara ASEAN mendukung peluang UMKM di NTB untuk dapat bersaing dengan Negara ASEAN lainnya yang merupakan potensi pasar yang cukup besar karena ASEAN menikmati pertumbuhan ekonomi terbesar didunia selain Asia selatan dan Asia timur.

Dari faktor internal UMKM di Indonesia memiliki peluang yang cukup besar, dimana pertumbuhan ekonomi Indonesia memiliki pertumbuhan ekonomi yang paling tinggi di antara negara-negara ASEAN lainnya yang mencapai pertumbuhan ekonomi $6,4 \%$ pada tahun 2011, menurut data bank dunia pertumbuhan ekonomi yang tinggi ini menciptakan peningkatan kelas menengah yang cukup besar di Indonesia yang mencapai 56,6\% pada tahun 2010 atau mencapai 134 juta jiwa, tentunya akan meningkatkan potensi pasar bagi UMKM yang ada di Indonesia terutama UMKM di Nusa Tenggara Barat (NTB). Peluang lainnya dari faktor internal yaitu Potensi pengembangan industri nasional yang menitikberatkan pada kegiatan produksi dikawasan dengan ditopang oleh adanya pasar domestik yang cukup besar, penduduk usia muda/produktif, investasi yang meningkat dan sumber daya alam yang cukup besar yang dimiliki oleh bangsa Indonesia. Total PDB Indonesia pada tahun 2011 merupakan PDB terbesar diantara Negara-negara ASEAN yang mencapai nilai sebesar US\$846 milyar atau terbesar ke-16 di dunia, hal ini berarti bahwa pendapatan masyarakat mengalami peningkatan yang tentunya akan dapat meningkatkan konsumsi masyarakat terhadap barang dan jasa, dimana peningkatan PDB ini menjadi peluang bagi UMKM untuk memperluas pasar dan mengembangkan produknya.

Dari sisi serapan tenaga kerja di Indonesia UMKM di Indonesia memiliki peranan yang strategis sebagai tulang-punggung perekonomian nasional dan regional (ASEAN) yang memiliki kontribusi yang cukup besar yang mampu menyerap sebanyak $97,2 \%$ dari seluruh tenaga kerja di Indonesia dengan jumlah UMKM lebih dari 55,2 juta atau terbesar di ASEAN. Peluang UMKM di NTB dalam menghadapi MEA 2015 adalah ditetapkannya NTB sebagai daerah pengembangan ekonomi diwilayah timur Indonesia yang masuk kedalam program MP3EI dengan basis pengembangan ekonomi pariwisata, karena NTB memiliki berbagai objek wisata alam yang sangat indah yang akan menjadi tujuan wisatawan mancanegara, dengan ditetapkannya NTB masuk ke dalam program MP3EI maka peluang UMKM di daerah ini sangat besar dalam memperluas pasar dan menjajakan produk UMKM tersebut kepada wisatawan domestic maupun wisatawan mancanegara.

\section{Analisis Tantangan UMKM NTB dalam menghadapi MEA}

Tantangan yang dihadapi oleh UMKM di NTB berasal dari faktor internal dan faktor eksternal, dimana tantangan dari faktor internal berasal dari UMKM itu sendiri seperti permasalahan Tingkat kemampuan/keahlian (SDM) yang masih kurang dibandingkan dengan usaha sedang atau besar yang telah menggunakan SDM yang professional dan memiliki skill yang tinggi, Manajerial yang kurang dimana 
UMKM di NTB masih menggunakan manajemen tradisional yang berbasis pada pengambilan keputusan manajerial pada satu orang saja sehingga setiap keputusan menjadi tidak maksimal, tantangan lain yang dihadapi oleh UMKM di NTB adalah akses pasar dan pemasaran yang kurang dimana pemasaran produk UMKM hanya berada di sekitar sentra UMKM itu sendiri dan masih mengandalkan pola pemasaran tradisional sehingga produk-produk UMKM di NTB tidak dapat diserap oleh pasar yang lebih luas. Selain itu juga permasalahan UMKM di NTB yang paling utama adalah keterbatasan modal usaha dimana sebagai besar modal usaha UMKM di NTB masih menggunakan modal seadanya yang berasal dari pemilik usaha maupun berasal dari pinjaman saudara atau koperasi yang tentunya memiliki keterbatasan sehingga UMKM di NTB sulit berkembang dan tentunya sulit untuk melakukan ekspansi usaha ke daerah lain.

Permasalahan yang menjadi tantangan bagi UMKM di NTB yang berasal dari faktor Eksternal adalah kurangya Pembinaan terhadap UMKM berupa pelatihanpelatihan manajemen usaha seperti pelatihan manajemen pemasaran, keuangan, produksi dan sumber daya manusia baik dari pemerintah pusat maupun dari pemerintah daerah, kalaupun ada pelatihan-pelatihannya hanya sebatas pada ceramah dan tidak ada tindak lanjut atau kontinuitas dalam memberikan pelatihan tersebut sehingga UMKM di NTB selalu tertinggal dari UMKM daerah lainnya. Selain itu juga Sinkronisasi program \& kebijakan yang berkaitan dengan pengembangan UMKM antara pemerintah pusat dan pemerintah daerah masih kurang dalam menghadapi pasar tunggal ASEAN MEA 2015 karena dengan adanya sinkronisasi pengembangan UMKM diharapkan kebijakan pemerintah akan dapat berjalan dengan baik antara pemerintah pusat dan pemerintah daerah.

\section{KESIMPULAN DAN SARAN}

\section{Kesimpulan}

1. Peluang UMKM NTB dalam menghadapi MEA 2015 terlihat dari potensi pasar ASEAN yang cukup besar yang mencapai 500 juta dollar Amerika dengan pertumbuhan kelas menengah yang semakin meningkat mencapai peningkatan sebesar $65 \%$ dan ditunjang oleh kebijakan makro ekonomi Negara-negara ASEAN yang cukup mendukung peningkatan peluang masuknya Foreign Direct Investment dari luar negeri dimana sampai dengan tahun 2010 total Foreign Direct Investment dari luar negeri yang masuk ke Negara-negara ASEAN telah mengalami peningkatan yang cukup signifikan mencapai $75 \%$.

2. Peluang UMKM di NTB dalam menghadapi MEA 2015 juga terlihat dari ditetapkannya NTB sebagai daerah pengembangan ekonomi diwilayah timur Indonesia yang masuk kedalam program MP3EI dengan basis pengembangan ekonomi pariwisata, karena NTB memiliki berbagai objek wisata alam yang sangat indah yang akan menjadi tujuan wisatawan mancanegara, dengan ditetapkannya NTB masuk ke dalam program MP3EI maka peluang UMKM di daerah ini sangat besar dalam memperluas pasar dan menjajakan produk UMKM 
tersebut kepada wisatawan domestic maupun wisatawan mancanegara.

3. Tantangan yang dihadapi oleh UMKM di NTB adalah Tingkat kemampuan/keahlian (SDM) yang masih kurang dibandingkan dengan usaha sedang atau besar yang telah menggunakan SDM yang profesional dan memiliki skill yang tinggi, Manajerial yang kurang dimana UMKM di NTB masih menggunakan manajemen tradisional, akses pasar dan pemasaran yang kurang dimana pemasaran produk UMKM hanya berada di sekitar sentra UMKM itu sendiri dan masih mengandalkan pola pemasaran tradisional, keterbatasan modal usaha juga menjadi tantangan UMKM di NTB dimana sebagai besar modal usaha UMKM di NTB masih menggunakan modal seadanya.

\section{Saran}

1. Perlu adanya Sinkronisasi program \& kebijakan yang berkaitan dengan pengembangan UMKM antara pemerintah pusat dan pemerintah daerah dalam menghadapi pasar tunggal ASEAN MEA 2015 karena dengan adanya sinkronisasi pengembangan UMKM diharapkan kebijakan pemerintah akan dapat berjalan dengan baik.

2. Diperlukan Pembinaan terhadap UMKM dari pemerintah pusat dan daerah berupa pelatihan-pelatihan manajemen usaha seperti pelatihan manajemen pemasaran, keuangan, produksi dan sumber daya manusia dan pelatihan, sosialisasi yang berkaitan dengan MEA 2015 agar pelaku UMKM di NTB paham apa itu MEA dan tentunya dapat mempersiapkan diri dalam bersaing menghadapi MEA dengan UMKM Negara-negara ASEAN. 


\section{DAFTAR PUSTAKA}

Anonim, UU Republik Indonesia No 9 tahun 1995 tentang Usaha Mikro Kecil Menengah (UMKM)

Dipta, Wayan. Tantangan dan kesiapan UMKM Indonesia dalam menghadapi MEA 2015.

Kuncoro, Mudrajad.2003. Ekonomi Pembangunan: Teori, Masalah dan Kebijakan, UPP-edisi ke-3, AMP YKPN, Yogyakarta.

Krugman Paul.R \& Obstfeld, Maurice. 2003. International Economics: Theory and Policy. Sixth Edition.Mc Graw Hill New York USA

Nopirin, 1999, Ekonomi Internasional, Edisi Ketiga, BPFE UGM, Yogyakarta.

Sri Susilo, Y. 2010. Strategi Meningkatkan Daya Saing UMKM Dalam Menghadapi Implementasi CAFTA Dan MEA. Buletin Ekonomi Vol. 8, No. 2, Agustus 2010 hal 70-170.

Tambunan, Tulus. Peluang, Tantangan Dan Ancaman Bagi UMKM Indonesia Dalam Era CAFTA Dan ME-ASEAN2015. Prosiding Seminar \& Konferensi Nasional Manajemen Bisnis, 26 Mei 2012

Tim Peneliti Bank Indonesia. 2009. Kajian Mengenai Standar Minimum Laporan Keuangan dan Business Plan untuk UMKM, Persiapan BI Dalam Menghadapi Masyarakat Ekonomi Asean (MEA) 2015 terkait dengan Tugas BI. Direktorat Kredit, BPR dan UMKM Bank Indonesia 